\title{
The RNA exosome affects iron response and sensitivity to oxidative stress
}

\author{
BORISLAVA TSANOVA, ${ }^{1}$ PHYLLIS SPATRICK, ${ }^{2}$ ALLAN JACOBSON, ${ }^{2}$ and AMBRO VAN HOOF ${ }^{1,3}$ \\ ${ }^{1}$ Department of Microbiology and Molecular Genetics, University of Texas Health Science Center-Houston and The University \\ of Texas Graduate School of Biomedical Sciences, Houston, Texas 77030, USA \\ ${ }^{2}$ Department of Microbiology and Physiological Systems, Albert Sherman Center, University of Massachusetts Medical School, Worcester, \\ Massachusetts 01655, USA
}

\begin{abstract}
RNA degradation plays important roles for maintaining temporal control and fidelity of gene expression, as well as processing of transcripts. In Saccharomyces cerevisiae the RNA exosome is a major $3^{\prime}$-to-5' exoribonuclease and also has an endonuclease domain of unknown function. Here we report a physiological role for the exosome in response to a stimulus. We show that inactivating the exoribonuclease active site of Rrp44 up-regulates the iron uptake regulon. This up-regulation is caused by increased levels of reactive oxygen species (ROS) in the mutant. Elevated ROS also causes hypersensitivity to $\mathrm{H}_{2} \mathrm{O}_{2}$, which can be reduced by the addition of iron to $\mathrm{H}_{2} \mathrm{O}_{2}$ stressed cells. Finally, we show that the previously characterized slow growth phenotype of $r r p 44-\mathrm{exo}^{-}$is largely ameliorated during fermentative growth. While the molecular functions of Rrp44 and the RNA exosome have been extensively characterized, our studies characterize how this molecular function affects the physiology of the organism.
\end{abstract}

Keywords: DIS3; RNA degradation; RRP44; yeast

\section{INTRODUCTION}

The exosome is a major exoribonuclease found in eukaryotes and archaea (Mitchell et al. 1997; Allmang et al. 1999b; Chekanova et al. 2002; Evguenieva-Hackenberg et al. 2003). In eukaryotes, including Saccharomyces cerevisiae, the exosome is a complex of 10 essential proteins, which in addition to its exonuclease activity also has an endonuclease activity (Lebreton et al. 2008; Schaeffer et al. 2009; Schneider et al. 2009). These catalytic activities are carried out by separate domains of the Rrp44 protein. The exosome is known to be located both in the nucleus and in the cytoplasm. In the nucleus it takes part of $3^{\prime}$ processing of the 5.8S rRNA, snoRNAs, snRNAs, and some mRNAs (Mitchell et al. 1996; Allmang et al. 1999a; van Hoof et al. 2000). It also degrades the $5^{\prime}$ external transcribed spacer (ETS) of rRNA, misprocessed RNAs such as hypomodified tRNA, and cryptic unstable transcripts (CUTs) (Kadaba et al. 2004; Milligan et al. 2008). In the cytoplasm, the exosome takes part in the degradation of normal, as well as aberrant, mRNAs (Jacobs Anderson and Parker 1998; van Hoof et al. 2002; Meaux and van Hoof 2006). Most of the activities of the exosome require the exoribonuclease activity of Rrp44, while the function of its endonuclease activity is enigmatic (Lebreton et al.

\footnotetext{
${ }^{3}$ Corresponding author

E-mail Ambro.van.hoof@uth.tmc.edu

Article published online ahead of print. Article and publication date are at http://www.rnajournal.org/cgi/doi/10.1261/rna.043257.113.
}

2008; Schaeffer et al. 2009; Schneider et al. 2009; Schaeffer and van Hoof 2011).

Studies of Rrp44's physiological function are limited. Rrp44 was shown to affect chromosome segregation, cell cycle progressions, and microtubules in Schizosaccharomyces pombe and S. cerevisiae (Murakami et al. 2007; Smith et al. 2011). Rrp44 has also been found to alter the circadian rhythm in Neusporra crassa (Guo et al. 2009). How any of these effects are related to the catalytic activities of Rrp44 is unknown. In addition to studies on Rrp44, it has been shown that the exosome components Rrp4 and Rrp41 have specific roles during early development of Arabidopsis thaliana (Chekanova et al. 2007). Here we characterize the effect of the catalytic activities of the exosome on the physiology of S. cerevisiae and find effects related to reactive oxygen species (ROS), iron uptake, and carbon utilization.

Iron is an essential element that functions in cellular metabolism because of its ability to be easily converted between oxidized and reduced forms, thus being a readily available electron donor or recipient. It is critical to maintain the precise balance of iron concentration inside the cell. Insufficient iron will adversely affect cellular metabolism since iron is a

\footnotetext{
(C) 2014 Tsanova et al. This article is distributed exclusively by the RNA Society for the first 12 months after the full-issue publication date (see http://rnajournal.cshlp.org/site/misc/terms.xhtml). After 12 months, it is available under a Creative Commons License (Attribution-NonCommercial 4.0 International), as described at http://creativecommons.org/licenses/ by-nc/4.0/.
} 
cofactor in many enzymatic reactions. Conversely, too much free iron is toxic to the cell because it takes part in the formation of damaging hydroxyl radical species through the Fenton reaction and leads to oxidative stress. Oxidative stress in turn has been known to damage all cellular components, including lipids, DNA, RNA, and proteins and in humans is related to several diseases, including neurodegenerative diseases such as ALS; Alzheimer's, Huntington's, and Parkinson's disease; and plaque formation in the arteries. It is also a contributing factor in the aging process (Trushina and McMurray 2007; Brieger et al. 2012; Chen and Keaney 2012; Gomez-Cabrera et al. 2012).

When yeast senses that its iron level is insufficient, it upregulates the master regulator of iron response, Aft 1 , which then binds to the promoter of genes required for iron uptake and induces their transcription (Crisp et al. 2003; Rutherford et al. 2005). The exact signal that is sensed and transduced to Aft1 is unknown, but it results in relocalization of Aft1. Under iron replete conditions. Aftl localizes to the cytoplasm, while activation of Aft1 causes its relocalization to the nucleus (Yamaguchi-Iwai et al. 1996, 2002).

As mentioned above, inappropriately high iron level causes production of ROS. Under normal iron levels, respiration is the major contributor to ROS production by electrons leaking from the electron transport chain (Herrero et al. 2008). During growth on glucose, $S$. cerevisiae suppresses the genes for respiration and grows by fermentation. When glucose is no longer available, it switches to respiration and oxidizes the remaining nonfermentable carbon source.

Here we show that inactivation of the exoribonuclease activity of the exosome results in the reduced ability of the cell to resist oxidative stress and up-regulates the iron uptake response. Moreover, we show that these effects and the significant growth defect of this strain are present during fermentative growth but not during respiratory growth. Overall, these results demonstrate that the molecular function of the exosome affects the physiology of the organism.

\section{RESULTS AND DISCUSSION}

\section{Activation of the iron-starvation response is a major physiological consequence of a defect in Rrp44 exonuclease activity}

We used microarray analysis to characterize the physiological effects of inactivating either the endoribonuclease or the exoribonuclease activity of the exosome. Specifically, we isolated polyadenylated RNA from quadruplicate cultures of wild type and two $\operatorname{rrp} 44$ mutants that have previously been characterized. The rrp44-exo-mutation changes Asp551 of the exonuclease active site to Asn, disrupts the exonuclease activity, and results in many RNA processing and degradation defects (Dziembowski et al. 2007). Importantly, although the exonuclease acts in mRNA decay, it only degrades mRNAs after deadenylation (Decker and Parker 1993; Jacobs Anderson and Parker 1998; Tucker et al. 2001). Therefore, direct mRNA targets of the exonuclease activity should accumulate in the deadenylated form and not be identified by microarray analysis of poly $(\mathrm{A})^{+}$RNA. Instead this analysis should reveal the physiological consequences of the rrp44-exo ${ }^{-}$mutation. The other mutation analyzed, rrp44-endo ${ }^{-}$, changes Asp171 of the endonuclease active site to Ala and disrupts the endonuclease activity but has no significant effect on known RNA processing and degradation roles of the exosome (Lebreton et al. 2008; Schaeffer et al. 2009; Schneider et al. 2009).

In our analysis we focused on mRNAs that were up-regulated at least twofold in at least three of the four biological replicates. We were surprised that even though the rrp44-exo ${ }^{-}$ mutation has a large effect on cell growth, the effects on gene expression were relatively modest, with 73 mRNAs upregulated and 63 down-regulated (Table 1; Supplemental Table S1). We found no mRNAs that were affected by the rrp44endo ${ }^{-}$mutation. Because the rrp44-endo- mutation has no measurable effect on growth or gene expression, it does not appear to perturb the cell even though the endoribonuclease active site is conserved in most if not all eukaryotes, and the activity has been shown to be conserved for the human ortho$\log$ hDIS3 (Tomecki et al. 2010). In addition to these mRNA targets, the rrp44-exo ${ }^{-}$microarray detected an increased level of polyadenylated ribosomal RNAs, which reflects the known role of the exosome in degradation of polyadenylated aberrant rRNAs (Kuai et al. 2004) and serves as a control to confirm the validity of the microarray approach.

We used gene ontology to analyze whether the mRNAs affected by the rrp44-exo ${ }^{-}$mutation were enriched in specific categories. All of the top gene ontology terms were related to iron uptake, including "iron chelate transport" $(P=7 \times$ $\left.10^{-11}\right)$ and "iron ion homeostasis" $\left(\mathrm{P}=1 \times 10^{-9}\right)$, and $16 \%$ of the mRNAs that were up-regulated were annotated with one or more gene ontology terms related to iron uptake (Table 1). To verify that the rrp44-exo- mutation indeed affected iron-starvation response genes, we isolated RNA from a second independently constructed rrp44-exo $^{-}$mutant strain and analyzed it by Northern blotting with probes for the FIT2 and CTH2/TIS11 mRNAs. As shown in Figure 1A, expression of both genes was also induced in this rrp44-exo strain. Therefore, we conclude that a major physiological consequence of the $\operatorname{rrp} 44-\mathrm{exo}^{-}$mutant is the up-regulation of the iron-starvation response.

The increased abundance of iron uptake-related mRNAs in an RNase mutant could be because that RNase directly degrades these mRNAs or because expression of a common regulator is affected by the RNase. The transcription factor Aft 1 is a major contributor to the iron-starvation response and is known to bind to ANTGCACCC (Yamaguchi-Iwai et al. 1996; Zhu et al. 2009). We therefore searched the 6623 intergenic regions of the yeast genome for ANTGCACCC and found 59 occurrences in 52 different intergenic regions. These elements were highly enriched in the intergenic regions just upstream of genes affected by $\operatorname{rrp} 44-e x o^{-}$. Specifically, 
TABLE 1. Genes up at least twofold in three of four microarrays for $r r p 44-e x 0^{-}$

\begin{tabular}{|c|c|c|c|c|c|}
\hline $\begin{array}{l}\text { Gene } \\
\text { name }\end{array}$ & ORF & $\begin{array}{l}\text { Fold up in } \\
\text { rrp44-exo }\end{array}$ & $\begin{array}{l}\text { Example iron- } \\
\text { related GO-term }\end{array}$ & $\begin{array}{c}\text { Perfect match } \\
\text { for } \\
\text { ANTGCACCC }\end{array}$ & Description \\
\hline FIT2 & YOR382W & 7.7 & $\begin{array}{l}\text { Iron chelate } \\
\text { transport }\end{array}$ & 4 & Siderophore-iron transporter \\
\hline FIT3 & YOR383C & 5.5 & $\begin{array}{l}\text { Iron chelate } \\
\text { transport }\end{array}$ & & Siderophore-iron transporter \\
\hline TIS11 & YLR136C & 5.5 & $\begin{array}{l}\text { Iron ion } \\
\text { homeostasis }\end{array}$ & 1 & mRNA-binding protein expressed during iron starvation \\
\hline ECM12 & YHR021W-A & 5.3 & & & Nonessential protein of unknown function \\
\hline PRM6 & YML047C & 5.1 & & & $\begin{array}{l}\text { Pheromone-regulated protein; predicted to have two } \\
\text { transmembrane segments }\end{array}$ \\
\hline \multirow[t]{2}{*}{ SIT1 } & YEL065W & 4.7 & $\begin{array}{l}\text { Iron chelate } \\
\text { transport }\end{array}$ & 1 & Ferrioxamine B transporter \\
\hline & YAL064W & 4.1 & & 1 & Hypothetical protein \\
\hline FIG1 & YBR040W & 4.0 & & & $\begin{array}{l}\text { Integral membrane; may participate in low affinity } \\
\mathrm{Ca}^{2+} \text { influx }\end{array}$ \\
\hline AGA2 & YGL032C & 3.9 & & & Adhesion subunit of a-agglutinin of a-cells \\
\hline DIP5 & YPL265W & 3.9 & & & Dicarboxylic amino acid permease \\
\hline GRE1 & YPL223C & 3.9 & & & Hydrophilin of unknown function; stress induced \\
\hline ARN1 & YHL040C & 3.8 & $\begin{array}{l}\text { Iron chelate } \\
\text { transport }\end{array}$ & 1 & Siderophore-iron transporter \\
\hline HMX1 & YLR205C & 3.7 & $\begin{array}{l}\text { Iron ion } \\
\quad \text { homeostasis }\end{array}$ & & $\begin{array}{l}\text { Heme-binding peroxidase involved in the degradation } \\
\text { of heme }\end{array}$ \\
\hline NRD1 & YNL251C & 3.7 & & & $\begin{array}{l}\text { RNA-binding protein for } 3^{\prime} \text { end maturation of } \\
\text { nonpolyadenylated RNAs }\end{array}$ \\
\hline SET6 & YPL165C & 3.5 & & & Protein of unknown function \\
\hline \multirow[t]{2}{*}{ ARP10 } & YDR106W & 3.4 & & & Actin-related protein \\
\hline & YOL162W & 3.4 & & & $\begin{array}{l}\text { Member of the Dal5p subfamily of the major facilitator } \\
\text { family }\end{array}$ \\
\hline $\mathrm{PDH} 1$ & YPR002W & 3.3 & & & Mitochondrial protein that participates in respiration \\
\hline GAT4 & YIR013C & 3.2 & & & Protein containing GATA family zinc finger motifs \\
\hline PRM5 & YIL117C & 3.2 & & & Pheromone-regulated protein \\
\hline HUG1 & YML058W-A & 3.2 & & & Protein involved in the Mec1p-mediated checkpoint \\
\hline VMR1 & YHL035C & 3.1 & & 1 & $\begin{array}{l}\text { Member of the ATP-binding cassette (ABC) family; potential } \\
\text { Cdc28p substrate }\end{array}$ \\
\hline ARN2 & YHL047C & 3.1 & $\begin{array}{l}\text { Iron chelate } \\
\text { transport }\end{array}$ & 1 & Siderophore-iron transporter \\
\hline MAL33 & YBR297W & 3.1 & & & MAL-activator protein \\
\hline FRE2 & YKL220C & 3.1 & $\begin{array}{l}\text { Iron ion } \\
\quad \text { transport }\end{array}$ & 1 & Ferric reductase and cupric reductase \\
\hline PRM2 & YIL037C & 3.0 & & & Pheromone-regulated protein \\
\hline TAD2 & YJL035C & 3.0 & & & tRNA-specific adenosine-34 deaminase \\
\hline IMD1 & YAR073W & 3.0 & & & Nonfunctional protein with homology to IMP dehydrogenase \\
\hline HES1 & YOR237W & 3.0 & & & Regulation of ergosterol biosynthesis \\
\hline TIR4 & YOR009W & 3.0 & & & Cell wall mannoprotein \\
\hline ALP1 & YNL270C & 2.9 & & & Basic amino acid transporter \\
\hline \multirow[t]{2}{*}{ NCA3 } & YJL116C & 2.9 & & & $\begin{array}{l}\text { Regulates expression of subunits } 6 \text { (Atp6p) and } 8 \text { (Atp8p) of } \\
\text { the Fo-F1 ATP synthase }\end{array}$ \\
\hline & YOL163W & 2.9 & & & $\begin{array}{l}\text { Member of the Dal5p subfamily of the major facilitator } \\
\text { family }\end{array}$ \\
\hline COS12 & YGL263W & 2.9 & & & Protein of unknown function \\
\hline MIG2 & YGL209W & 2.9 & & & Transcription factor involved in glucose repression \\
\hline INO1 & YJL153C & 2.8 & & & Inositol 1-phosphate synthase \\
\hline CIN1 & YOR349W & 2.8 & & & Tubulin folding factor \\
\hline RKM5 & YLR137W & 2.8 & & & Protein lysine methyltransferase \\
\hline FUS2 & YMR232W & 2.7 & & & Required for nuclear fusion during mating \\
\hline FYV5 & YCL058C & 2.7 & & & Involved in ion homeostasis \\
\hline MND1 & YGL183C & 2.7 & & & $\begin{array}{l}\text { Protein required for recombination and meiotic nuclear } \\
\text { division }\end{array}$ \\
\hline MFA1 & YDR461W & 2.7 & & & Mating pheromone a-factor \\
\hline
\end{tabular}


Tsanova et al.

TABLE 1. Continued

\begin{tabular}{|c|c|c|c|c|c|}
\hline $\begin{array}{l}\text { Gene } \\
\text { name }\end{array}$ & ORF & $\begin{array}{l}\text { Fold up in } \\
\text { rrp44-exo }\end{array}$ & $\begin{array}{l}\text { Example iron- } \\
\text { related GO-term }\end{array}$ & $\begin{array}{l}\text { Perfect match } \\
\quad \text { for } \\
\text { ANTGCACCC }\end{array}$ & Description \\
\hline & YLR108C & 2.7 & & & Hypothetical protein \\
\hline AYT1 & YLL063C & 2.7 & & & Acetyltransferase \\
\hline ZPS1 & YOL154W & 2.7 & & & GPI-anchored protein induced under low-zinc conditions \\
\hline FLO1 & YAR050W & 2.7 & & & Lectin-like protein involved in flocculation \\
\hline FET3 & YMR058W & 2.6 & $\begin{array}{l}\text { Iron ion } \\
\quad \text { homeostasis }\end{array}$ & & Ferro- $\mathrm{O}_{2}$-oxidoreductase \\
\hline \multirow[t]{2}{*}{ ARG82 } & YDR173C & 2.6 & & & Transcription factor for Arg biosynthesis \\
\hline & YNL024C & 2.6 & & & S-adenosylmethionine-dependent methyltransferase \\
\hline PRM1 & YNL279W & 2.5 & & & Protein involved in membrane fusion during mating \\
\hline MIG3 & YER028C & 2.5 & & & $\begin{array}{l}\text { Transcriptional repressor involved in response to toxic agents } \\
\text { such as hydroxyurea }\end{array}$ \\
\hline ENB1 & YOL158C & 2.4 & $\begin{array}{l}\text { Iron chelate } \\
\text { transport }\end{array}$ & 2 & Endosomal ferric enterobactin transporter \\
\hline AAD14 & YNL331C & 2.4 & & & Aryl-alcohol dehydrogenase \\
\hline RRN3 & YKL125W & 2.4 & & & Transcription of rDNA by RNA polymerase \\
\hline SPS1 & YDR523C & 2.4 & & & $\begin{array}{l}\text { Protein serine/threonine kinase expressed at the end } \\
\text { of meiosis }\end{array}$ \\
\hline CCC2 & YDR270W & 2.4 & $\begin{array}{l}\text { Iron ion } \\
\text { homeostasis }\end{array}$ & 2 & $\mathrm{Cu}^{2+}$-transporting P-type ATPase \\
\hline \multirow[t]{2}{*}{ SNO1 } & YMR095C & 2.4 & & & Protein of unconfirmed function \\
\hline & YIL089W & 2.3 & & & Hypothetical protein \\
\hline \multirow[t]{2}{*}{ DAN3 } & YBR301W & 2.3 & & & Cell wall mannoprotein \\
\hline & YBR284W & 2.3 & & & Hypothetical protein \\
\hline MTC3 & YGL226W & 2.3 & & & Hypothetical protein \\
\hline PCK1 & YKR097W & 2.3 & & & Phosphoenolpyruvate carboxykinasein the cytosol \\
\hline THI13 & YDL244W & 2.2 & & & thiamine synthesis \\
\hline LEE1 & YPL054W & 2.2 & & & Zinc-finger protein of unknown function \\
\hline CUE2 & YKL090W & 2.2 & & & Protein of unknown function \\
\hline FRE3 & YOR381W & 2.2 & $\begin{array}{l}\text { Iron chelate } \\
\text { transport }\end{array}$ & & Ferric reductase \\
\hline ATG10 & YLL042C & 2.1 & & & E2-like conjugating enzyme \\
\hline НХT9 & YJL219W & 2.1 & & & Putative hexose transporter \\
\hline AIM4 & YBR194W & 2.1 & & & $\begin{array}{l}\text { Protein proposed to be associated with the nuclear pore } \\
\text { complex }\end{array}$ \\
\hline IDH1 & YNL037C & 2.1 & & & Mitochondrial NAD(+)-dependent isocitrate dehydrogenase \\
\hline SHU2 & YDR078C & 2.1 & & & $\begin{array}{l}\text { Protein of unassigned function involved in mutation } \\
\text { suppression }\end{array}$ \\
\hline KAR4 & YCL055W & 2.1 & & & $\begin{array}{l}\text { Transcription factor required for induction of KAR3 and CIK1 } \\
\text { during mating }\end{array}$ \\
\hline SRD1 & YCR018C & 2.0 & & & Processing of pre-rRNA to mature rRNA \\
\hline
\end{tabular}

$25 \%$ of the elements were found in the intergenic regions just upstream of the 73 genes in our data set, including four elements upstream of the most affected gene (FIT2) (Table 1). Several other genes that were affected by $\operatorname{rrp} 44-$ exo $^{-}$had ANTGCACCC elements nearby or had imperfect matches. In addition, several genes that were induced less than our twofold threshold also had ANTGCACCC elements. We thus suspected that the rrp44-exo- mutation somehow affected the activity of the transcription factor Aft1, which in turn increased transcription of iron-uptake-related genes.

To test whether Aft1 activity is increased in the $\operatorname{rp} 44-$ exo $^{-}$ mutant, we constructed a lac $Z$ reporter gene by cloning the binding site for Aft 1 into a construct that contained a minimal promoter and the lac $Z$ ORF. The resulting reporter plasmid was transformed into $\operatorname{rrp} 44-$ exo $^{-}$and RRP44 strains, and $\beta$ galactosidase activity was measured in three transformants for each strain. Figure $1 \mathrm{~B}$ shows that $\beta$-galactosidase levels were increased 2.3-fold in the $\operatorname{rrp} 44-$ exo $^{-}$strain, which matches the effect we see on iron-starvation regulon genes. Expression of $\beta$-galactosidase from the parental plasmid that lacks an Aft1 binding site was not affected (Fig. 1B; Supplemental Fig. 1). These data suggest that the Aft1 transcription factor is in-

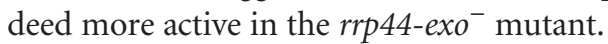

Aft1 regulation is mostly post-translational, such that Aft1 is localized in the cytoplasm under iron replete conditions and becomes relocalized to the nucleus when the cell senses a need for more iron (Yamaguchi-Iwai et al. 2002). We therefore compared the location of an Aft1-GFP fusion protein in 

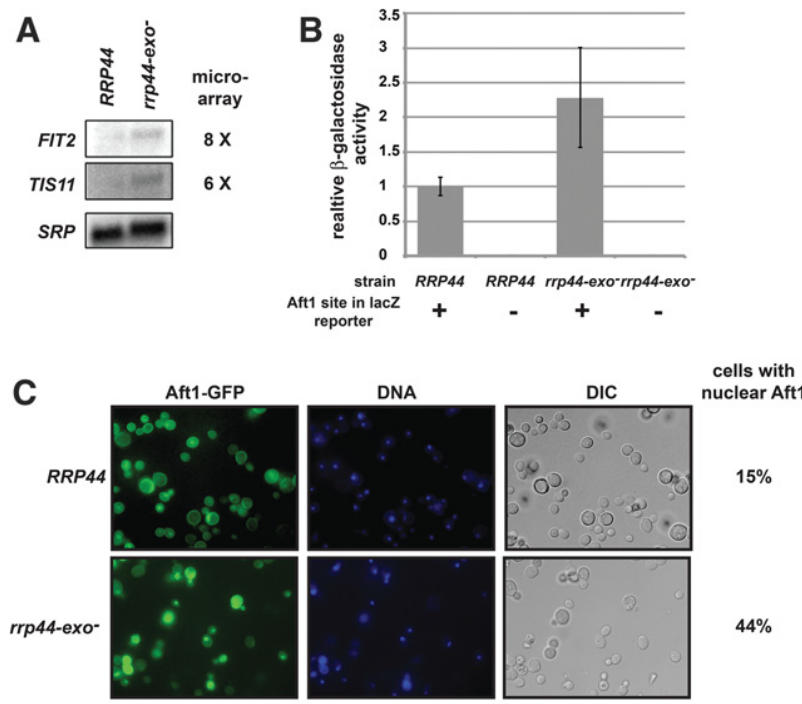
nuclear Aft1

$15 \%$

D

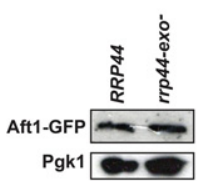

FIGURE 1. The Aft1 regulated iron regulon is activated in a rrp44-exo $^{-}$ mutant. (A) Northern blot analysis confirms the microarray results that the expression of FIT2 and TIS11 mRNAs is increased in an rrp44-exomutant. To the left of the blot is the fold increase in expression from the microarray analysis. SRP indicates the RNA subunit of the signal recognition particle, which is used as a loading control. (B) The rrp44-exo $^{-}$ mutation increases expression of a lac $Z$ reporter gene that contains a single Aft 1 binding site. The graph shows averages and standard deviations of triplicate cultures. As a control, a reporter gene without an Aft1 binding site is very poorly expressed and not affected by $\operatorname{rrp}_{44-e x o^{-}}$(see Supplemental Fig. 1). (C) An Aft1-GFP fusion protein was expressed in wild-type and $\operatorname{rrp} 44-$ exo $^{-}$mutant strains to localize Aft 1 . The percentage of cells that showed a nuclear localization of Aft1, reflecting activation of Aft1, is indicated on the right. (D) Western blot analysis of Aft1GFP in wild-type and $r r p 44-$ exo $^{-}$strains, using anti-GFP antibody. Pgk1 is used for loading control.

the rrp44-exo ${ }^{-}$mutant and RRP44 strains. Aft1 was observed to be concentrated in the nucleus of $44 \%$ of the rrp44-exo cells and in $15 \%$ of the RRP44 cells (Fig. 1C). We also analyzed expression levels of Aft1-GFP by Western blot and noted that they were similar in the wild-type and $\operatorname{rrp44-exo^{-}}$ strains (Fig. 1D). The enrichment of ANTGCACCC elements, increase in lac $Z$ expression, and increased nuclear localization of Aft 1 all indicate that the $\operatorname{rrp}^{4} 4-$ exo $^{-}$mutant activates the cellular iron-starvation response by somehow activating and relocalizing this key transcription factor.

\section{Inactivation of the exonuclease activity of Rrp44 increases hydrogen peroxide sensitivity and intracellular ROS levels}

Iron is both an essential element because it is a cofactor for many proteins and a toxic element because iron reacts to generate ROS. To further characterize the effect of the increase in
Aft1 activity and the resulting up-regulation of the iron-starvation regulon, we analyzed growth under low- and high-iron conditions, as well as oxidative stress. To analyze the effect of iron concentration in the media, we compared four different growth conditions: SC media with the standard iron concentration $\left.(0.2 \mathrm{mg} / \mathrm{L} \mathrm{FeCl})_{3}\right)$, SC media with 1000 -fold increase in iron, SC media with no added iron but with trace iron available from the water or other ingredients, and SC media with no added iron and added iron chelator bathophenanthrolinedisulfonate (BPS). These conditions did not reveal any specific effects on the rrp44-exo ${ }^{-}$mutant; the rrp44-exo ${ }^{-}$mutant grows slower than an isogenic RRP44 strain under the first three conditions, and neither the wild-type nor mutant strains grew in the presence of BPS. We conclude that the up-regulation of the iron-starvation regulon we detected in the rrp44-exo ${ }^{-}$strain does not significantly affect its ability to grow under iron-excess or iron-starvation conditions.

To test the effects of $\operatorname{rrp} 44-$ exo $^{-}$mutant further, we tested if this mutant was sensitive to exposure to oxidative stress. As shown in Figure 2A, the rrp44-exo ${ }^{-}$mutant did not grow on
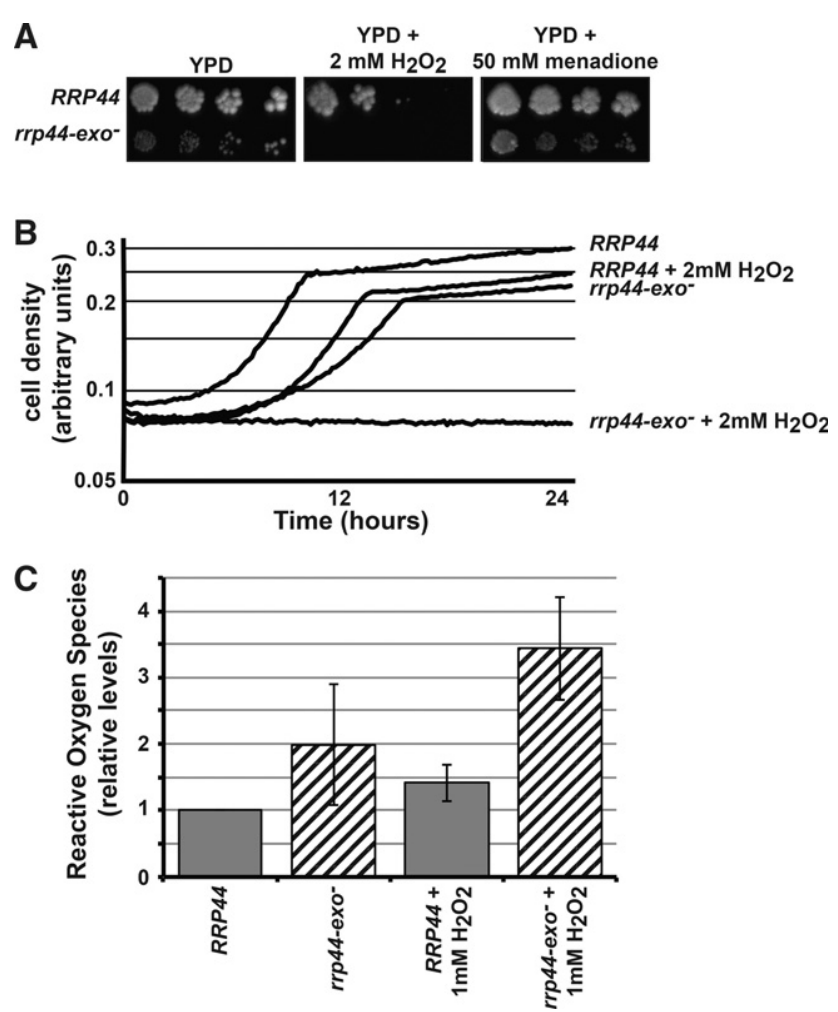

FIGURE 2. The rrp44-exo ${ }^{-}$is hypersensitive to $\mathrm{H}_{2} \mathrm{O}_{2}$. (A) The rrp44exo- mutant is hypersensitive to hydrogen peroxide when grown on solid media. Shown are the RRP44 and rrp44-exo ${ }^{-}$strains grown on solid media either without added reactive oxygen species (ROS) or with added hydrogen peroxide or the superoxide generating compound menadione. $(B)$ Shown are growth curves of the RRP44 and rrp44-exo ${ }^{-}$strains grown in liquid media in the presence or absence of $\mathrm{H}_{2} \mathrm{O}_{2}$. (C) The rrp44-exostrain hyperaccumulates ROS. Intracellular ROS levels were measured in RRP44 and rrp44-exo ${ }^{-}$strains grown in the presence or absence of $1 \mathrm{mM} \mathrm{H}_{2} \mathrm{O}_{2}$. 
YPD plates supplemented with $2 \mathrm{mM} \mathrm{H}_{2} \mathrm{O}_{2}$, indicating increased sensitivity to oxidative stress. Under these same conditions, the wild-type strain did grow, although at a slightly slower rate than in the absence of $\mathrm{H}_{2} \mathrm{O}_{2}$. We observed similar effects during growth in liquid media: Addition of $2 \mathrm{mM}$ $\mathrm{H}_{2} \mathrm{O}_{2}$ had a modest effect on the growth rate of the RRP44 control strain but completely eliminated growth of the rrp44-exo ${ }^{-}$mutant (Fig. 2B). This hypersensitivity was specific to $\mathrm{H}_{2} \mathrm{O}_{2}$ because the superoxide-generating agent menadione affected the wild type and the $\operatorname{rrp} 44-$ exo $^{-}$mutant approximately equally (Fig. 2A). In addition to the lowand high-iron stress. other stresses such as growth at high or low temperature did not specifically affect the growth of the rrp44-exo ${ }^{-}$strain compared with the wild type, further demonstrating the specificity of the $\mathrm{H}_{2} \mathrm{O}_{2}$ sensitivity.

Hypersensitivity to oxidative stress could result from inability to repair damage caused by normal levels of ROS, it could be due to increased levels of intracellular ROS, or both. To test whether ROS levels were altered in the rrp44exo- mutant, we used $2^{\prime}, 7^{\prime}$-dichlorodihydrofluorescein diacetate $\left(\mathrm{H}_{2} \mathrm{DCFDA}\right) . \mathrm{H}_{2}$ DCFDA is not fluorescent, but upon hydrolysis by intracellular esterases and oxidation by ROS, it is transformed into the fluorescent compound $2^{\prime}, 7^{\prime}$ dichlorofluorescein (DCF). Thus, intracellular ROS levels can be detected by measuring fluorescence after $\mathrm{H}_{2}$ DCFDA exposure. By use of this assay, we detected a 2.0-fold higher level of ROS in the rrp44-exo- mutant compared with the mutant during growth in the absence of added ROS and a 2.4-fold higher level after exposure to $1 \mathrm{mM} \mathrm{H}_{2} \mathrm{O}_{2}$ (Fig. 2C). We therefore conclude that the $\operatorname{rrp} 44-\mathrm{exo}^{-}$mutant accumulates increased amounts of ROS.

\section{Altered iron response and sensitivity to oxidative

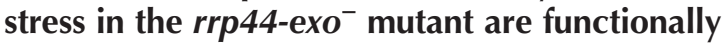 connected}

Knowing the $\operatorname{rrp} 44-$ exo $^{-}$mutant has both an up-regulated iron response and increased ROS, we decided to test if these were related. We could envision at least two possible ways these are linked. Aftl activity is not directly controlled by iron but instead is controlled by the availability of iron-sulfur clusters (Chen et al. 2004; Rutherford et al. 2005). Since hydrogen peroxide damages iron-sulfur clusters, it is possible that the excess ROS in $\operatorname{rrp} 44-$ exo $^{-}$decreases the availability of iron-sulfur clusters, which would result in Aft1 induction. Thus, under this scenario the $\operatorname{rrp} 44-$ exo $^{-}$mutant responds appropriately to a decreased level of available iron-sulfur clusters that is caused by an increased ROS level. Alternatively, $\operatorname{rrp} 44-$ exo $^{-}$may inappropriately up-regulate Aft1 and the resulting increased intracellular Fe levels would cause an increased production of ROS due to the reactivity of iron ions.

To distinguish between these two possibilities, we first exposed the $\operatorname{rrp} 44$-exo ${ }^{-}$mutant to $1 \mathrm{mM} \mathrm{H}_{2} \mathrm{O}_{2}$ for $1 \mathrm{~h}$ and then removed the $\mathrm{H}_{2} \mathrm{O}_{2}$ and added extra iron to the media. This addition of extra iron after $\mathrm{H}_{2} \mathrm{O}_{2}$ exposure increased growth of the rrp44-exo ${ }^{-}$strain. (Fig. 3A, cf. red and green solid lines). In comparison, adding iron to RRP44 cells that were treated with ROS did not significantly change their growth (Fig. 3A, dashed lines). Similarly, adding iron to $\operatorname{rrp44-exo^{-}}$ or RRP44 in the absence of $\mathrm{H}_{2} \mathrm{O}_{2}$ stress did not significantly affect their growth (Fig. 3B). These data support the first possibility that increased ROS levels lead to a decreased level of available iron-sulfur clusters, which in turn results in Aft 1 activation. This possibility suggests that adding $\mathrm{H}_{2} \mathrm{O}_{2}$ to $R R P 44$ cells should have a similar effect of Aft 1 activation. Figure $3 \mathrm{C}$ shows that, indeed, the FIT2 mRNA is up-regulated upon exposure of wild-type cells to $\mathrm{H}_{2} \mathrm{O}_{2}$. The effects of $\mathrm{H}_{2} \mathrm{O}_{2}$ and rrp44-exo ${ }^{-}$were not additive; at low concentrations of $\mathrm{H}_{2} \mathrm{O}_{2}$, the rrp44-exo ${ }^{-}$mutant did not show a further increase in FIT2 expression, while at higher concentrations of $\mathrm{H}_{2} \mathrm{O}_{2}$, the RRP44 and rrp44-exo ${ }^{-}$strains responded similarly (Fig. 3C). Taken together, these data suggest that the rrp44-exomutant has a higher requirement for iron and responds appropriately to this requirement by up-regulating the iron regulon.

\section{The exonuclease activity of the exosome is required for normal growth rate during fermentative conditions but not during respiratory conditions}

When yeast is grown under standard laboratory conditions in YEP $+2 \%$ glucose, it initially ferments the glucose to ethanol and, only after glucose is depleted, respires the ethanol to $\mathrm{CO}_{2}$. The above experiments and most published experiments with exosome mutants use log phase cells that almost exclusively ferment. Under these circumstances, ROS production is relatively low, and iron needs are likely to be low as well, since a number of mitochondrial proteins required for respiration contain Fe-S clusters. Therefore, to extend our understanding of the physiological effects of the rrp44exo ${ }^{-}$mutant beyond the fermentative conditions, we compared its growth rate to the wild-type strain under conditions where yeast can only respire. Specifically, we compared

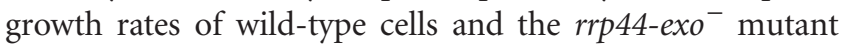
on media with glycerol or ethanol instead of glucose as a carbon source. Glycerol and ethanol are nonfermentable and require the cells to grow by respiration. Figure 4A shows that wild-type and $\operatorname{rrp} 44-\mathrm{exo}^{-}$strains grow with similar rates when grown on YEP plates with $2 \%$ glycerol or $2 \%$ ethanol. Growth in liquid culture revealed that the $\operatorname{rrp} 44-$ exo ${ }^{-}$mutant grew slightly slower than the wild type, but the difference was much less pronounced than during fermentative growth (Fig. 4B). To test whether expression of Rrp44 was different during fermentative and respiratory growth, we performed Western blot on an epitope-tagged strain. Figure 4C shows that Rrp44 levels during growth on YPD and YEP $+2 \%$ glycerol were similar. Thus, the less-pronounced growth defect of Rrp44exo ${ }^{-}$during respiratory growth is not correlated with reduced expression of the protein. 
A
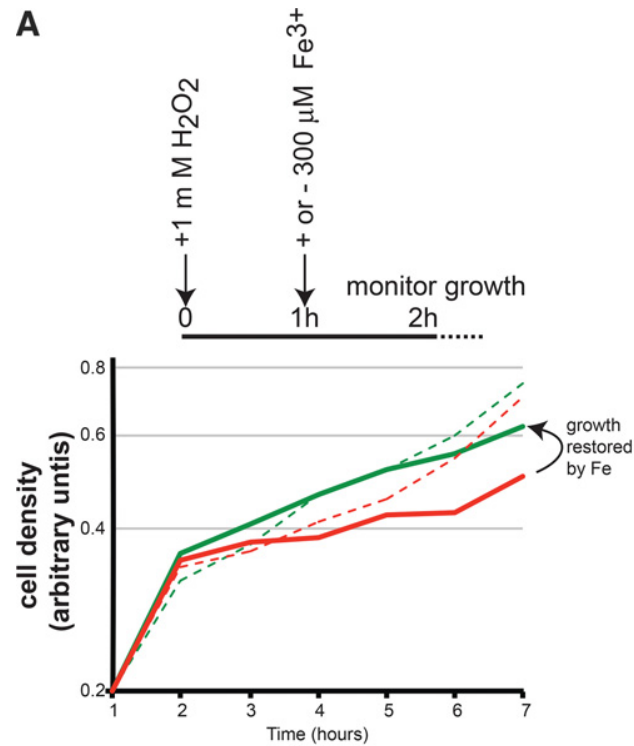

C

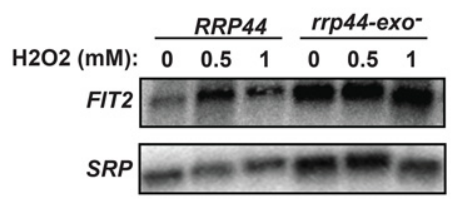

B
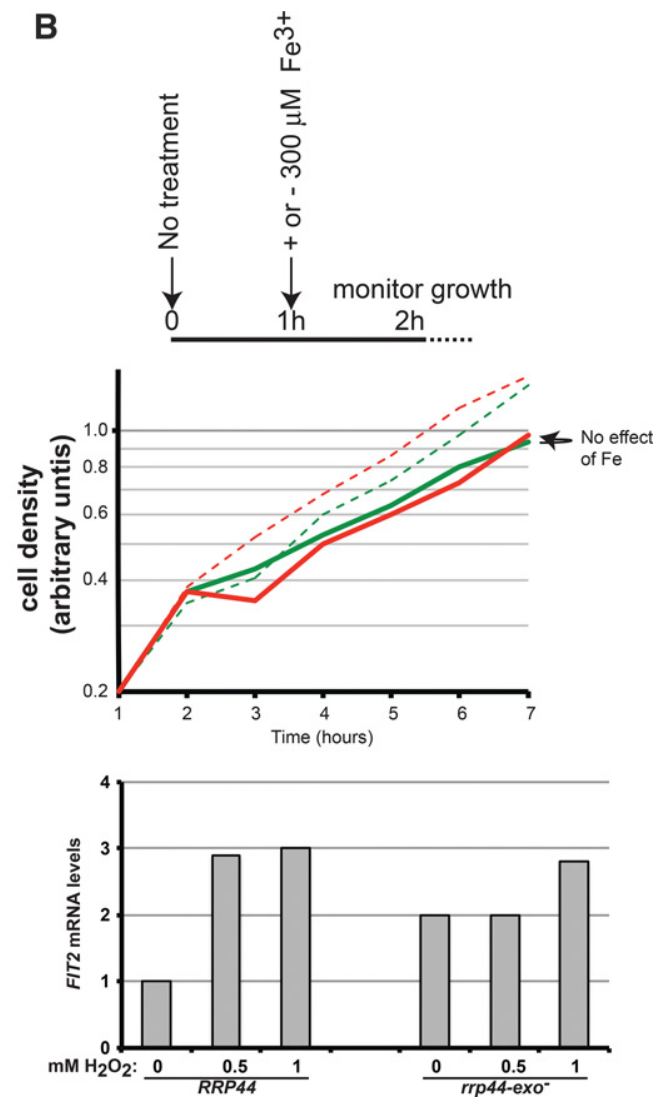

FIGURE 3. Sensitivity to oxidative stress in the $r r p 44-e^{-} o^{-}$mutant is functionally related to the altered iron response. (A) Growth inhibition of the rrp44-exo ${ }^{-}$after $1 \mathrm{~h}$ exposure to $1 \mathrm{mM} \mathrm{H}_{2} \mathrm{O}_{2}$ can be suppressed by addition of extra iron to the media. Solid lines indicate growth curves of the rrp44exo $\sigma^{-}$mutant; dashed lines, growth curves of a RRP44 control strain. Green indicates growth after addition of iron; red, growth in the absence of extra iron. (B) Addition of extra iron has no effect in the absence of prior $\mathrm{H}_{2} \mathrm{O}_{2}$ treatment. Colors and solid versus dashed lines as in A. (C) The FIT2 mRNA is induced by exposure to $\mathrm{H}_{2} \mathrm{O}_{2}$, and this effect is not additive with the effect of the rrp44-exo ${ }^{-}$mutation. Shown is a representative Northern blot (left) and its quantitation (right). The SRP RNA served as a loading control as in Figure 1.

Our observations that the rrp44-exo ${ }^{-}$strain is hypersensitive to ROS and has a slow growth phenotype specifically during fermentative growth appear paradoxical, since ROS production should be low during fermentation. To resolve this puzzle, we measured ROS levels during respiratory growth and found that under these conditions the rrp44exo ${ }^{-}$mutant had levels of ROS comparable to wild type (Fig. 4C), presumably because mechanisms to detoxify ROS are also up-regulated during respiratory growth. Thus, these observations further strengthen the correlation between the growth defect of rrp44-exo ${ }^{-}$and ROS accumulation.

Because the rrp44-exo ${ }^{-}$mutant has a growth defect during fermentative growth on glucose but has much less of a growth defect during respiratory growth, we also analyzed whether it was inefficient in converting glucose to biomass. Specifically, we simultaneously measured biomass accumulation (by measuring optical density) and glucose depletion during growth in YEP $+2 \%$ glucose. As shown in Figure $4 \mathrm{D}$ the wild type and rrp44-exo ${ }^{-}$mutant converted glucose to biomass with very similar efficiency. Therefore, the slow growth during fermentation is not due to inefficient conversion of glucose to biomass.
The exonuclease activity of the exosome is required for RNA processing and degradation during fermentative and respiratory conditions

Yeast growth is typically coordinated with ribosome production (Waldron and Lacroute 1975; Mager and Planta 1991). This suggests the possibility that the slow growth phenotype of the rrp44-exo ${ }^{-}$strain is related to its known defect in ribosomal RNA maturation. Thus, to characterize the relation between slow growth and this rRNA processing defect, we isolated RNA from the wild-type and rrp44-exo ${ }^{-}$mutant strains growing in fermentative or respiratory conditions and analyzed it by Northern blotting. Figure 5A shows that the aberrant 5.8S rRNA processing intermediates present in the rrp44-exo ${ }^{-}$strain during growth on glucose are also present during growth on glycerol (marked with an asterisk in Fig. 5). Similarly, the known defects of the rrp44-exo ${ }^{-}$mutant in $5^{\prime}$ ETS degradation (Fig. 5B) and U4 snRNA (Fig. 5C) processing were present, even when grown on glycerol. Therefore, we conclude that the growth defect exhibited by rrp44-exo ${ }^{-}$during fermentative growth is independent of these specific processing and degradation defects and that 

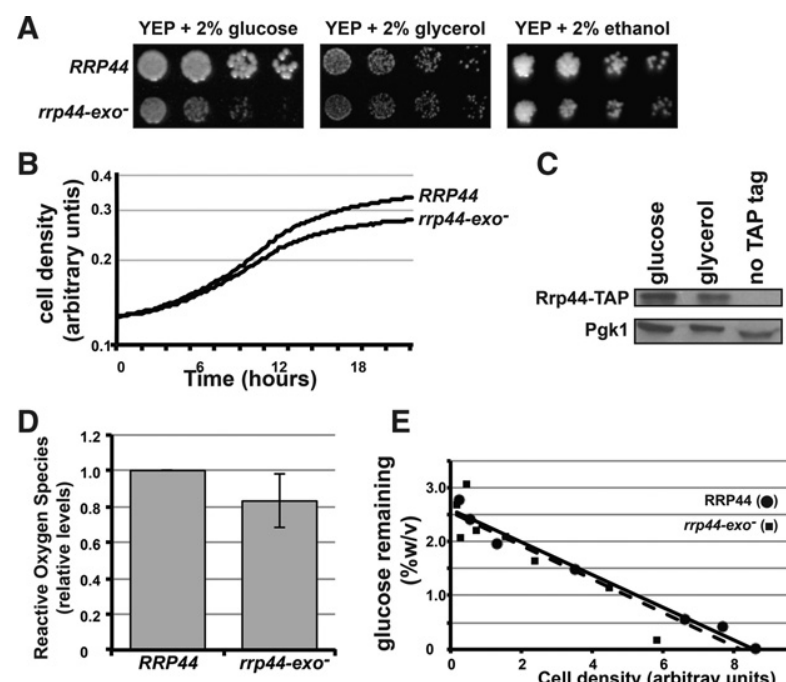

E

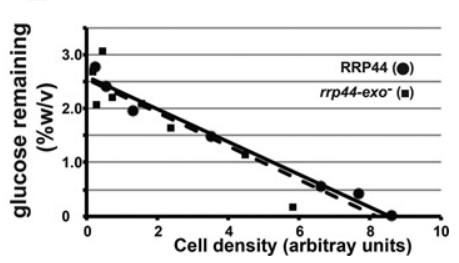

FIGURE 4. Lack of the Rrp44 exonuclease activity results in slow growth under fermentative but not respiratory growth. (A) Shown are the RRP44 and rrp44-exo ${ }^{-}$strains grown on solid media either with fermentable glucose or with nonfermentable glycerol or ethanol as the carbon source. (B) Shown are growth curves of the RRP44 and rrp44-exo strains grown in liquid media with glycerol as the carbon source (cf. with the growth in medium with glucose in Fig. 2A). (C) Western blot analysis of TAP-tagged Rrp44 levels during fermentative (glucose) and respiratory (glycerol) growth. Pgk1 is used as a loading control. (D) The rrp44-exo ${ }^{-}$strain does not hyperaccumulate intracellular ROS when grown in media with glycerol as the carbon source (cf. with ROS accumulation when grown in media with glucose in Fig. 2C). (E) The rrp44exo ${ }^{-}$mutant grows slowly in media containing glucose but is not inefficient in converting glucose to biomass. The mutant and wild-type strains were grown in YPD media, and growth $\left(\mathrm{OD}_{600}\right)$ and glucose levels were monitored every $2 \mathrm{~h}$ and plotted.

the exonuclease activity of the exosome is required for RNA processing and degradation during fermentative and respiratory conditions.

\section{CONCLUSIONS}

Our results suggest that the major physiological consequence of inactivating the exonuclease of Rrp44 is an increase in ROS accumulation, which results in an increased need for iron and a decreased growth rate under fermentative conditions. Although the RNA exosome has been extensively studied at the molecular level and mutants that reduce RNA exosome activity cause slow growth, how the RNA exosome affects the physiological state of the cell was previously largely unknown. To investigate this, we used a microarray approach to identify genes that were up- or down-regulated in response to inactivating the active site residues of the main catalytic subunit of the exosome. Despite the very slow growth of the rrp44-exo ${ }^{-}$strain, the number of genes affected was surprisingly low and dominated by genes in the iron-uptake regulon. The main transcription factor for this regulon is Aft 1 , and we show that expression of a lac $Z$ reporter gene that incorporates a single binding site for Aft1 is increased in the rrp44-exo ${ }^{-}$mutant. We further confirmed that Aft1 is activated by showing that a GFP fusion is translocated into the nucleus. Aft1 activation and nuclear import have been shown to be directed by a pair of glutaredoxins (Grx3 and Grx4), which by an unknown mechanism respond to the level of available iron-sulfur clusters (Ojeda et al. 2006; Pujol-Carrion et al. 2006).

Strikingly, three different RNases and RNA degradation pathways have previously been implicated in the regulation of the iron response. First, RRP6 encodes a nuclear cofactor of the exosome, and iron regulon RNAs were shown to increase in rrp6 $\Delta$ strains (Lee et al. 2005; Houalla et al. 2006; Ciais et al. 2008). The molecular mechanism behind this up-regulation was not fully explored, but it was suggested that iron regulon mRNAs were likely direct targets of the nuclear exosome (Lee et al. 2005; Houalla et al. 2006; Ciais et al. 2008). In contrast, our findings of up-regulation in rrp44-exo ${ }^{-}$ can be fully explained by activation of the Aft1 transcription factor, and we do not suspect that these mRNAs are direct Rrp44 targets. A further difference is that the increased CTH2 mRNA level in rrp6 $\Delta$ is mostly due to accumulation of $3^{\prime}$ extended mRNAs (Ciais et al. 2008), which we did not detect in rrp44-exo ${ }^{-}$. Thus rrp6 $\Delta$ and $r r p 44-$ exo $^{-}$appear to have different effects on iron regulon mRNAs, which likely reflect two different mechanisms of control. The second RNase previously implicated in expression of iron-uptake-related mRNAs is the endonuclease Rnt1 (Lee et al. 2005). Rnt1 and Rrp44 also appear to function in separate pathways because genes up-regulated in $r n t 1 \Delta$ were not enriched for Aft 1 targets, $r n t 1 \Delta$ resulted in decreased expression of lacZ re-

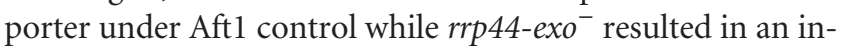
creased expression, and the rrp44-exo ${ }^{-}$mutation increases expression of FIT2 mRNA while $r n t 1 \Delta$ decreases its expression. Finally, CTH2, one of the Aft1 targets that we find upregulated in rrp44-exo ${ }^{-}$, encodes an RNA binding protein that controls decapping of specific mRNAs by Dcp2 followed by Xrn1-mediated degradation (Puig et al. 2005; PedroSegura et al. 2008), but the target mRNAs of Cth2 differ from the Aft1 targets that we find up-regulated in rrp44exo ${ }^{-}$. Recently, a second RNA binding protein, Air2, has also been implicated in the regulation of the iron regulon (Schmidt et al. 2012). Air2 is a cofactor of the exosome and Schmidt et al. (2012) reported that the FIT2 mRNA level is reduced in an $\operatorname{rrp} 6 \Delta$ strain but increased in an $\operatorname{rrp} 6 \Delta$ air $2 \Delta$ double mutant. This suggests that Air2p acts in an Rrp6independent pathway to affect FIT2 mRNA. Whether this Air2-dependent pathway is the same as the pathway we describe here remains to be determined. Overall, these results indicate that iron homeostasis is regulated by at least four different RNases_-Rrp44, Rrp6, Rnt1, and Dcp2/Xrn1, and the available evidence indicates that each of these RNases acts in different pathways.

We also show that the rrp44-exo- mutant strain accumulates ROS. Because ROS are especially reactive with iron-sulfur clusters, we hypothesize that this increased ROS causes a 


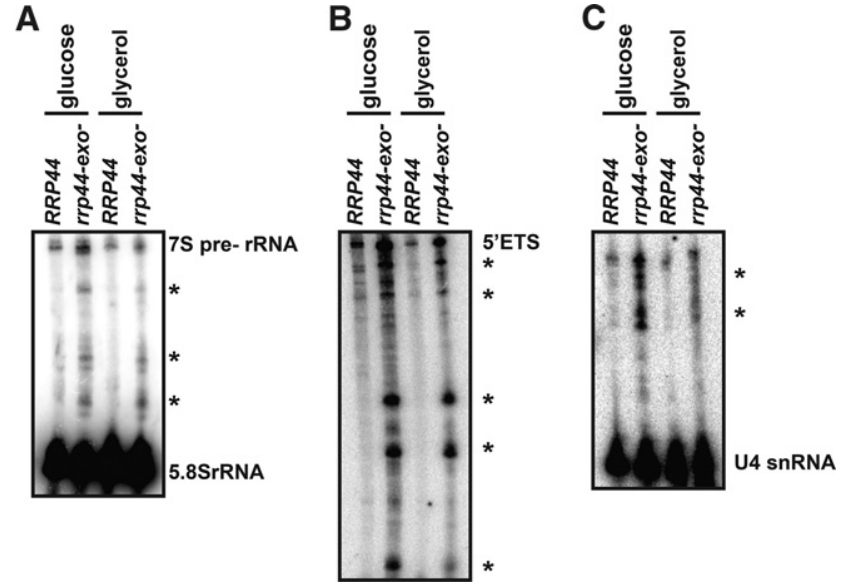

FIGURE 5. Although the growth defect of $\mathrm{rrp}^{4} 4$-exo $^{-}$is specific for fermentative growth, the known RNA processing defects are seen during both fermentative and respiratory growth. The RRP44 and rrp44-exo strains were grown in YEP + glucose or YEP + glycerol as indicated. RNA was isolated and analyzed by Northern blotting with probes specific for $5.8 \mathrm{~S}$ rRNA $(A)$, the $5^{\prime}$ external transcribed spacer of the pre-rRNA (5' ETS; $B$ ), or the U4 snRNA $(C)$. RNA species that accumulate in the rrp44-exo ${ }^{-}$mutant are indicated with asterisks.

reduction in the level of iron-sulfur clusters, which turns on the Aft1 regulon. Our observations that the hydrogen peroxide sensitivity of rrp44-exo ${ }^{-}$can be suppressed by adding iron and that the iron regulon is induced upon addition of hydrogen peroxide to wild-type cells are consistent with this possibility. The molecular mechanism of how the exonuclease activity of the RNA exosome affects this signaling pathway remains unknown. However, the exosome has been shown to be required for the degradation of long noncoding RNAs (Lebreton et al. 2008), which can affect gene expression. For example, the expression of SER3 in response to serine starvation is regulated by the noncoding RNA SRG1 (Martens et al. 2004, 2005). One possibility is that a similar noncoding RNA affects expression of a key regulator that controls ROS levels.

Although the exosome has many known functions, it is not known which of these functions is most critical for normal growth or whether multiple important aspects of cell physiology are perturbed in exosome mutants. Here we show that the growth defect of $\operatorname{rrp} 44-$ exo $^{-}$is much more severe under fermentative conditions than under respiratory conditions. In addition, under conditions where rrp44-exo ${ }^{-}$ grows slowly, this strain hyperaccumulates ROS, whereas under conditions where it does not hyperaccumulate ROS, growth is much more similar to that of the wild type. In contrast, the 5.8S rRNA and U4snRNA processing and 5' ETS degradation defects seen in the mutant do not correlate with a defect in growth rate. Thus, our results suggest the possibility that the ROS hyperaccumulation we observe is a major contributor to the slow growth seen in this and possibly other exosome mutants.

\section{MATERIALS AND METHODS}

\section{Yeast strains}

All strains were derived from the heterozygous diploid RRP44/ rrp44A::NEO strain obtained from Open Biosystems using standard yeast genetics techniques as previously described (Schaeffer et al. 2009). The microarray analysis was done on quadruplicate cultures of yAV1129, yAV1131, and yAV1135. Follow-up experiments were done with these same strains as well as a second independent isolate of rrp44-exo ${ }^{-}$, yAV1284. All experiments were done at least in duplicate. To generate a second independent isolate of $r r p 44-e x o^{-}$, first the ORF for NEO resistance was replaced by an ORF encoding Nourseothricin resistance (NAT) by transforming the RRP44/ rrp44ム::NEO strain obtained from Open Biosystems with p4339 (Tong and Boone 2006) obtained from Dr. Charlie Boone's laboratory. Next the rrp44-exo ${ }^{-}$plasmid was introduced as previously described (Schaeffer et al. 2009). The genotypes of the strains used are as follows:

yAV1129 (wild-type strain): Mata, leu2- $\Delta 0$, ura3- $\Delta 0$, his3- $\Delta 1$, $\operatorname{rrp} 44 \Delta::$ NEO [RRP44, LEU2];

yAV1131 (rrp44-exo ${ }^{-}$): Mata, leu2- $\Delta 0$, ura3- $\Delta 0$, his3- $\Delta 1, \operatorname{rrp} 44 \Delta:$ : NEO [rrp44D551N, LEU2];

yAV1135 (rrp44-endo ${ }^{-}$): Mata, leu2- $\Delta 0$, ura3- $\Delta 0$, his3- $\Delta 1$, rrp444:: NEO [rrp44D171A, LEU2]; and

yAV1284 (rrp44-exo ${ }^{-}$): leu2- $\Delta 0$, ura3- $\Delta 0$, his3- $\Delta 1$, lys2- $\Delta 0, \operatorname{rrp} 44 \Delta::$ NAT [rrp44D551N, LEU2].

\section{Plasmids}

The RRP44, rrp44-exo ${ }^{-}$, and rrp44-endo ${ }^{-}$plasmids have previously been described (Schaeffer et al. 2009). The Aft1-GFP plasmid has also been described (Crisp et al. 2003) and was kindly provided by Dr. Jerry Kaplan (University of Utah). The lacZ control plasmid pCM64 was kindly provided by Dr. Kevin Morano (University of Texas Health Science Center Houston). pCM64 is a derivative of pLG669-Z (Guarente and Ptashne 1981) with the 434-bp Xhol fragment replaced with a linker introducing a unique BglII site. The Aft1-lacZ reporter plasmid pAV804 is a derivative of PCM64 with the Aft1 binding site form the FET3 promoter inserted into the unique BglII site. pAV804 was generated by cloning oAV886 (GATCTCTTCAAAAGTGCACCCATTTGCAGGTGCTCC) and oAV887 (TCGAGGAGCACCTGCAAATGGGTGCACTTTTGAAGA) into the BglII site of pCM64.

\section{Media and growth conditions}

All growth assays were repeated at least three times. Unless otherwise indicated, all cultures were started overnight in $5 \mathrm{~mL} \mathrm{YPD}$ and then transferred the following day to the specified media. Growth was at $30^{\circ} \mathrm{C}$ unless otherwise noted. YPD (YEP + glucose), YEP + glycerol, YEP + ethanol, and SC media were prepared as previously described (Burke et al. 2000). Yeast nitrogen base (catalog no. 1501-250), yeast nitrogen base lacking iron (catalog no. 1551-100), and the amino acids mixes were from Sunrise Science. The iron chelator BPS was from Sigma-Aldrich (catalog no. 146617-1G). For the experiments in Figure 3, ammonium iron(III) sulfate dodecahydrate was from Sigma Aldrich (catalog no. 221260-25G). Glucose levels were 
measured using a glucose (HK) assay kit (Sigma-Aldrich catalog no. GAHK20-1KT) according to the manufacturer's instructions.

For growth assays on solid media, fivefold serial dilutions of S. cerevisiae cells were made in a 96-well plate starting with $\mathrm{OD}_{600}=0.6$. These were then spotted on the indicated media and incubated at $30^{\circ} \mathrm{C}$ (unless otherwise indicated).

Liquid growth assays were performed either in 96-well plates in a Synergy MX automated microplate reader or in test tubes.

\section{Microscopy}

Cells were transformed with the Aft1-GFP plasmid and grown in selective media. Before microscopy, cells were stained with Hoechst 33342 stain for $10 \mathrm{~min}$, washed with $\mathrm{H}_{2} \mathrm{O}$, and observed with an Olympus IX81 microscope.

\section{$\beta$-galactosidase assay}

Strains containing either pCM64 or pAV804 were grown to $\mathrm{OD}_{600}$ $=0.6$, and $\beta$-galactosidase activity was measured using the Beta-Glo reagent (Promega) according to the manufacturer's instructions using a Biotech Synergy MX plate reader. Briefly, $50 \mu \mathrm{L}$ of culture was mixed with $50 \mu \mathrm{L}$ of $\beta$-glo reagent in a 96-well microtiter plate, incubated for $30 \mathrm{~min}$, and light production measured and normalized to $\mathrm{OD}_{600}$. Similar results were obtained when $\beta$-galactosidase activity was measured using ortho-nitrophenyl- $\beta$-galactoside (ONPG).

\section{ROS detection}

Cultures were either treated with the indicated concentrations of $\mathrm{H}_{2} \mathrm{O}_{2}$ or left untreated. After $1 \mathrm{~h}$ treatment, $1 \mathrm{~mL}$ of culture was centrifuged and the cells washed in phosphate buffered saline (PBS) and resuspended in $1 \mathrm{~mL}$ PBS containing $25 \mu \mathrm{M}$ H2DCFDA. Fluorescence was detected at $525 \mathrm{~nm}$ with excitation at $495 \mathrm{~nm}$. Fluorescence was normalized to $\mathrm{OD}_{600}$.

\section{RNA isolation and analysis}

Liquid cultures $(5 \mathrm{~mL})$ were grown overnight at $30^{\circ} \mathrm{C}$. The cultures were then diluted into $20 \mathrm{~mL}$ of fresh media to an $\mathrm{OD}_{600}$ of 0.125 and grown at $30^{\circ} \mathrm{C}$ to an $\mathrm{OD}_{600}$ of 0.6 . The culture was briefly centrifuged, and the cell pellet was collected, washed once with $\mathrm{ddH}_{2} \mathrm{O}$, and either used immediately or frozen at $-80^{\circ} \mathrm{C}$ prior to RNA extraction. RNA was extracted as previously described ( $\mathrm{He}$ et al. 2008 ), separated on $6 \%$ polyacrylamide or $1.3 \%$ agarose gels, and blotted onto Zeta-Probe membrane (Biorad). The blots were probed with $5^{\prime} \mathrm{P}^{32}$-labeled oligonucleotides for FIT2 mRNA (CGACGG CTTGAGTGACGGTC), TIS11 mRNA (GGGAGTTTCCTGCAC TTGGC), 5.8S rRNA (TTTCGCTGCGTTCTTCATC), 5' ETS (CGAACGACAAGCCTACTG), U4 snRNA (CGGACGAATCCT CACTGATA), and the RNA subunit of the signal recognition particle (SRP; GTCTAGCCGCGAGGAAGG) as a loading control.

For the microarray experiments, quadruplicate cultures of yAV1129, yAV1131, and yAV1135 were grown in YPD, and RNA was isolated and processed as described previously ( $\mathrm{He}$ et al. 2003). Fragmented cRNA was prepared using the Affymetrix 3'IVT express kit and was hybridized to Affymetrix Yeast Genome
2.0 arrays. The relative abundance of each transcript was determined using Affymetrix Microarray Suite 5.0.

\section{SUPPLEMENTAL MATERIAL}

Supplemental material is available for this article.

\section{ACKNOWLEDGMENTS}

We thank Drs. Kevin Morano, Charlie Boone, and Jerry Kaplan for plasmids, as well as Kevin Morano for use of the 96-well plate reader. This work was supported by grants from the NIH (5R01GM099790) and The Welch Foundation (AU-1773) to A.v.H. and from the NIH (R37GM27757) to A.J.

Received October 30, 2013; accepted April 1, 2014.

\section{REFERENCES}

Allmang C, Kufel J, Chanfreau G, Mitchell P, Petfalski E, Tollervey D. 1999a. Functions of the exosome in rRNA, snoRNA and snRNA synthesis. EMBO J 18: 5399-5410.

Allmang C, Petfalski E, Podtelejnikov A, Mann M, Tollervey D, Mitchell P. 1999b. The yeast exosome and human PM-Scl are related complexes of $3^{\prime} \rightarrow 5^{\prime}$ exonucleases. Genes Dev 13: 2148-2158.

Brieger K, Schiavone S, Miller FJ Jr, Krause KH. 2012. Reactive oxygen species: from health to disease. Swiss Med Wkly 142: w13659.

Burke D, Dawson D, Stearns T. 2000. Methods in yeast genetics: a Cold Spring Harbor Laboratory course manual. Cold Spring Harbor Laboratory Press, Cold Spring Harbor, NY.

Chekanova JA, Dutko JA, Mian IS, Belostotsky DA. 2002. Arabidopsis thaliana exosome subunit AtRrp4p is a hydrolytic $3^{\prime} \rightarrow 5^{\prime}$ exonuclease containing S1 and KH RNA-binding domains. Nucleic Acids Res 30: 695-700.

Chekanova JA, Gregory BD, Reverdatto SV, Chen H, Kumar R, Hooker T, Yazaki J, Li P, Skiba N, Peng Q, et al. 2007. Genomewide high-resolution mapping of exosome substrates reveals hidden features in the Arabidopsis transcriptome. Cell 131: 1340-1353.

Chen K, Keaney JF Jr. 2012. Evolving concepts of oxidative stress and reactive oxygen species in cardiovascular disease. Curr Atheroscler Rep 14: 476-483.

Chen OS, Crisp RJ, Valachovic M, Bard M, Winge DR, Kaplan J. 2004. Transcription of the yeast iron regulon does not respond directly to iron but rather to iron-sulfur cluster biosynthesis. J Biol Chem 279: 29513-29518.

Ciais D, Bohnsack MT, Tollervey D. 2008. The mRNA encoding the yeast ARE-binding protein Cth 2 is generated by a novel $3^{\prime}$ processing pathway. Nucleic Acids Res 36: 3075-3084.

Crisp RJ, Pollington A, Galea C, Jaron S, Yamaguchi-Iwai Y, Kaplan J. 2003. Inhibition of heme biosynthesis prevents transcription of iron uptake genes in yeast. J Biol Chem 278: 45499-45506.

Decker CJ, Parker R. 1993. A turnover pathway for both stable and unstable mRNAs in yeast: evidence for a requirement for deadenylation. Genes Dev 7: 1632-1643.

Dziembowski A, Lorentzen E, Conti E, Seraphin B. 2007. A single subunit, Dis3, is essentially responsible for yeast exosome core activity. Nat Struct Mol Biol 14: 15-22.

Evguenieva-Hackenberg E, Walter P, Hochleitner E, Lottspeich F, Klug G. 2003. An exosome-like complex in Sulfolobus solfataricus. EMBO Rep 4: 889-893.

Gomez-Cabrera MC, Sanchis-Gomar F, Garcia-Valles R, ParejaGaleano H, Gambini J, Borras C, Vina J. 2012. Mitochondria as sources and targets of damage in cellular aging. Clin Chem Lab Med 50: 1287-1295. 
Guarente L, Ptashne M. 1981. Fusion of Escherichia coli lacZ to the cytochrome $c$ gene of Saccharomyces cerevisiae. Proc Natl Acad Sci 78: 2199-2203.

Guo J, Cheng P, Yuan H, Liu Y. 2009. The exosome regulates circadian gene expression in a posttranscriptional negative feedback loop. Cell 138: 1236-1246.

He F, Li X, Spatrick P, Casillo R, Dong S, Jacobson A. 2003. Genomewide analysis of mRNAs regulated by the nonsense-mediated and $5^{\prime}$ to $3^{\prime}$ mRNA decay pathways in yeast. Mol Cell 12: 1439-1452.

He F, Amrani N, Johansson MJ, Jacobson A. 2008. Chapter 6. Qualitative and quantitative assessment of the activity of the yeast nonsense-mediated mRNA decay pathway. Methods Enzymol 449: 127-147.

Herrero E, Ros J, Belli G, Cabiscol E. 2008. Redox control and oxidative stress in yeast cells. Biochim Biophys Acta 1780: 1217-1235.

Houalla R, Devaux F, Fatica A, Kufel J, Barrass D, Torchet C, Tollervey D. 2006. Microarray detection of novel nuclear RNA substrates for the exosome. Yeast 23: 439-454.

Jacobs Anderson JS, Parker RP. 1998. The $3^{\prime}$ to $5^{\prime}$ degradation of yeast mRNAs is a general mechanism for mRNA turnover that requires the SKI2 DEVH box protein and $3^{\prime}$ to $5^{\prime}$ exonucleases of the exosome complex. EMBO J 17: 1497-1506.

Kadaba S, Krueger A, Trice T, Krecic AM, Hinnebusch AG, Anderson J. 2004. Nuclear surveillance and degradation of hypomodified initiator tRNA ${ }^{\text {Met }}$ in S. cerevisiae. Genes Dev 18: 1227-1240.

Kuai L, Fang F, Butler JS, Sherman F. 2004. Polyadenylation of rRNA in Saccharomyces cerevisiae. Proc Natl Acad Sci 101: 8581-8586.

Lebreton A, Tomecki R, Dziembowski A, Seraphin B. 2008. Endonucleolytic RNA cleavage by a eukaryotic exosome. Nature 456: 993-996.

Lee A, Henras AK, Chanfreau G. 2005. Multiple RNA surveillance pathways limit aberrant expression of iron uptake mRNAs and prevent iron toxicity in S. cerevisiae. Mol Cell 19: 39-51.

Mager WH, Planta RJ. 1991. Coordinate expression of ribosomal protein genes in yeast as a function of cellular growth rate. Mol Cell Biochem 104: 181-187.

Martens JA, Laprade L, Winston F. 2004. Intergenic transcription is required to repress the Saccharomyces cerevisiae SER3 gene. Nature 429: 571-574.

Martens JA, Wu PY, Winston F. 2005. Regulation of an intergenic transcript controls adjacent gene transcription in Saccharomyces cerevisiae. Genes Dev 19: 2695-2704.

Meaux S, van Hoof A. 2006. Yeast transcripts cleaved by an internal ribozyme provide new insight into the role of the cap and poly(A) tail in translation and mRNA decay. RNA 12: 1323-1337.

Milligan L, Decourty L, Saveanu C, Rappsilber J, Ceulemans H, Jacquier A, Tollervey D. 2008. A yeast exosome cofactor, Mpp6, functions in RNA surveillance and in the degradation of noncoding RNA transcripts. Mol Cell Biol 28: 5446-5457.

Mitchell P, Petfalski E, Tollervey D. 1996. The $3^{\prime}$ end of yeast 5.8S rRNA is generated by an exonuclease processing mechanism. Genes Dev 10: 502-513.

Mitchell P, Petfalski E, Shevchenko A, Mann M, Tollervey D. 1997. The exosome: a conserved eukaryotic RNA processing complex containing multiple $3^{\prime} \rightarrow 5^{\prime}$ exoribonucleases. Cell 91: 457-466.

Murakami H, Goto DB, Toda T, Chen ES, Grewal SI, Martienssen RA, Yanagida M. 2007. Ribonuclease activity of Dis3 is required for mitotic progression and provides a possible link between heterochromatin and kinetochore function. PLoS One 2: e317.

Ojeda L, Keller G, Muhlenhoff U, Rutherford JC, Lill R, Winge DR. 2006. Role of glutaredoxin- 3 and glutaredoxin- 4 in the iron regulation of the Aft 1 transcriptional activator in Saccharomyces cerevisiae.J Biol Chem 281: 17661-17669.

Pedro-Segura E, Vergara SV, Rodriguez-Navarro S, Parker R, Thiele DJ, Puig S. 2008. The Cth2 ARE-binding protein recruits the
Dhh1 helicase to promote the decay of succinate dehydrogenase SDH4 mRNA in response to iron deficiency. J Biol Chem 283: 28527-28535.

Puig S, Askeland E, Thiele DJ. 2005. Coordinated remodeling of cellular metabolism during iron deficiency through targeted mRNA degradation. Cell 120: 99-110.

Pujol-Carrion N, Belli G, Herrero E, Nogues A, de la Torre-Ruiz MA. 2006. Glutaredoxins Grx3 and Grx4 regulate nuclear localisation of Aftl and the oxidative stress response in Saccharomyces cerevisiae. J Cell Sci 119(Pt 21): 4554-4564.

Rutherford JC, Ojeda L, Balk J, Muhlenhoff U, Lill R, Winge DR. 2005. Activation of the iron regulon by the yeast Aft1/Aft2 transcription factors depends on mitochondrial but not cytosolic iron-sulfur protein biogenesis. J Biol Chem 280: 10135-10140.

Schaeffer D, van Hoof A. 2011. Different nuclease requirements for exosome-mediated degradation of normal and nonstop mRNAs. Proc Natl Acad Sci 108: 2366-2371.

Schaeffer D, Tsanova B, Barbas A, Reis FP, Dastidar EG, SanchezRotunno M, Arraiano CM, van Hoof A. 2009. The exosome contains domains with specific endoribonuclease, exoribonuclease and cytoplasmic mRNA decay activities. Nat Struct Mol Biol 16: $56-62$.

Schmidt K, Xu Z, Mathews DH, Butler JS. 2012. Air proteins control differential TRAMP substrate specificity for nuclear RNA surveillance. RNA 18: 1934-1945.

Schneider C, Leung E, Brown J, Tollervey D. 2009. The N-terminal PIN domain of the exosome subunit Rrp44 harbors endonuclease activity and tethers Rrp44 to the yeast core exosome. Nucleic Acids Res 37: $1127-1140$.

Smith SB, Kiss DL, Turk E, Tartakoff AM, Andrulis ED. 2011. Pronounced and extensive microtubule defects in a Saccharomyces cerevisiae DIS3 mutant. Yeast 28: 755-769.

Tomecki R, Kristiansen MS, Lykke-Andersen S, Chlebowski A, Larsen KM, Szczesny RJ, Drazkowska K, Pastula A, Andersen JS, Stepien PP, et al. 2010. The human core exosome interacts with differentially localized processive RNases: hDIS3 and hDIS3L. EMBO J 29: 2342-2357.

Tong AH, Boone C. 2006. Synthetic genetic array analysis in Saccharomyces cerevisiae. Methods Mol Biol 313: 171-192.

Trushina E, McMurray CT. 2007. Oxidative stress and mitochondrial dysfunction in neurodegenerative diseases. Neuroscience 145: $1233-1248$.

Tucker M, Valencia-Sanchez MA, Staples RR, Chen J, Denis CL, Parker R. 2001. The transcription factor associated Ccr4 and Caf1 proteins are components of the major cytoplasmic mRNA deadenylase in Saccharomyces cerevisiae. Cell 104: 377-386.

van Hoof A, Lennertz P, Parker R. 2000. Yeast exosome mutants accumulate 3 -extended polyadenylated forms of U4 small nuclear RNA and small nucleolar RNAs. Mol Cell Biol 20: 441-452.

van Hoof A, Frischmeyer PA, Dietz HC, Parker R. 2002. Exosome-mediated recognition and degradation of mRNAs lacking a termination codon. Science 295: 2262-2264.

Waldron C, Lacroute F. 1975. Effect of growth rate on the amounts of ribosomal and transfer ribonucleic acids in yeast. J Bacteriol 122: 855-865.

Yamaguchi-Iwai Y, Stearman R, Dancis A, Klausner RD. 1996. Iron-regulated DNA binding by the AFT1 protein controls the iron regulon in yeast. $E M B O J$ 15: 3377-3384.

Yamaguchi-Iwai Y, Ueta R, Fukunaka A, Sasaki R. 2002. Subcellular localization of Aft1 transcription factor responds to iron status in Saccharomyces cerevisiae. J Biol Chem 277: 18914-18918.

Zhu C, Byers KJ, McCord RP, Shi Z, Berger MF, Newburger DE, Saulrieta K, Smith Z, Shah MV, Radhakrishnan M, et al. 2009. High-resolution DNA-binding specificity analysis of yeast transcription factors. Genome Res 19: 556-566. 

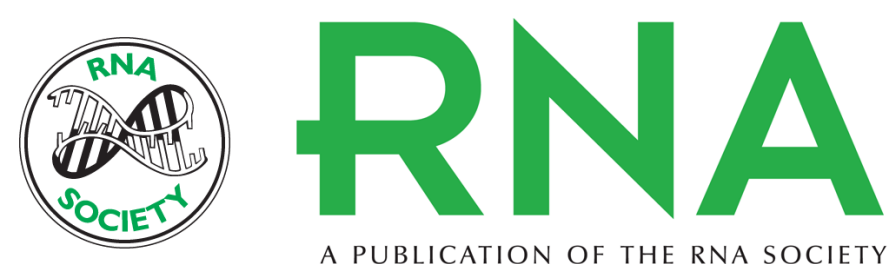

A PUBLICATION OF THE RNA SOCIETY

\section{The RNA exosome affects iron response and sensitivity to oxidative stress}

Borislava Tsanova, Phyllis Spatrick, Allan Jacobson, et al.

RNA 2014 20: 1057-1067 originally published online May 23, 2014

Access the most recent version at doi:10.1261/rna.043257.113

\section{Supplemental http://rnajournal.cshlp.org/content/suppl/2014/05/06/rna.043257.113.DC1 Material}

References This article cites 52 articles, 25 of which can be accessed free at: http://rnajournal.cshlp.org/content/20/7/1057.full.html\#ref-list-1

Creative This article is distributed exclusively by the RNA Society for the first 12 months after the Commons License full-issue publication date (see http://rnajournal.cshlp.org/site/misc/terms.xhtml). After 12 months, it is available under a Creative Commons License (Attribution-NonCommercial 4.0 International), as described at http://creativecommons.org/licenses/by-nc/4.0/.

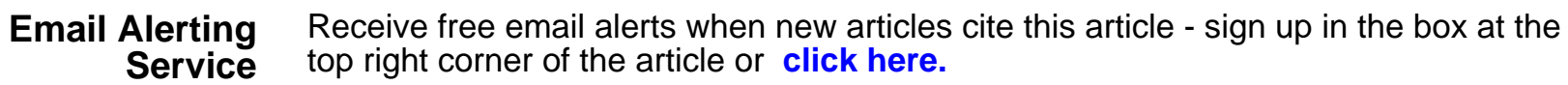

